\title{
THE COLLECTED POEMS OF ALICE MEYNELL
}

THE substance of most books of modern verse is the succession of scattered emotions remaining to those who have no philosophy of life, who cannot see the wood for the trees, who suffer the ache of an inner vacuity, who clutch at the passing straw of any transient emotion because that wandering wisp is the only tangible thing in the disorder of their attention. But an ache for something which is not there, a confession of something wanting, a search for some centre on which to repose : none of these is a substitute for a positive quality. It is the absence of a personality which these reveal ; they are symptoms, not revelations. The lack which earnestness, striving, purpose (ugly words for ugly vices) betray in life and in prose, this scatter-brained emotionalism betrays in poetry. The first cannot speak, nor the second sing. This explains why we read most contemporary books of verse with impatience, and why, if we read many of them, all sense of standard seems to depart from us.

Here I have tried to make the effort which most readers will hardly be at pains to make for themselves, the effort to diagnose the disorder of which most modern verse is the reflection. Since this dis-ease, with the disillusion which accompanies it, is now endemic, we should recognize its nature and then fortify ourselves by a study of those writers, classical and modern, who in different degrees belong to the true order of poetry. This order is to be recognized by its affirmative note and by the unmistakable presence of attention. Now full attention will be awakened only by recognition of some reality. It will have a centre of gravity, however small, from which, as from the sun or from the daisy, rays of light will spread to the joy of every eye once focussed upon it. For the 


\section{The Collected Poems of Alice Meynell}

poet is always the seer ; and though we boast that he merely expresses that which we already know, he gives us, in truth, his eyes for a moment, his eyes as well as that whereon they have rested. The multitude of books of modern verse, then, is a triumph not of education, but of machinery. The faster the number grows the more important does it become to return to the standard set by the few, the true poets among them. Mrs. Meynell, like Mr. W. H. Davies, must bear her share of the common burden, and submit without undue dismay to another appreciation of herself:

The reception of her work has been somewhat curious. The early volume was well received by those whose praise was worth having. Then she turned to prose, and that was also praised, mainly, I think, by the rank and file of critics, except in the case of Patmore, who preferred the prose to the verse! What did she think of his preference? It is hard for a writer who began with verse, and whose verse was applauded, to find her prose preferred thereto; the harder the greater the critic. I can fancy that Mrs. Meynell would have weighed his words more than those of others, and that her response would have been, not "It is unfair to say that," but simply "Is it true ?" Since she returned to verse, she must on reflection have said to herself : "A writer has two media. He need not limit himself to one. To seek to limit himself in accordance with the verdict of others would be to surrender to the critics who are far too apt to interfere. I shall write a poem, gentlemen, when the mood is upon me, and an essay when I will." At this point in her reflections the drawing-room door was opened, and the ghostly line of critics took their leave.

It is possible that the preference has changed since then. For myself I am on the side of the verses, 


\section{Blackfriars}

because they are free from a quality which may be discerned in the prose, the quality (how far is it a quality ?) of preciousness. The only prose to which this essay must refer is that provided by the titles. Anyone acquainted with the essays would recognize the author of a poem called Renouncement, and the author of another poem entitled The Lover urges the Better Thrift. Let us pause upon these titles for a moment. Though there is precedent for the old word renouncement, no Englishman would use it until he had first thought of, and then rejected, renunciation. It is not idiomatic. It is correct, but a trifle too conscious of its correctness. It attracts our notice to itself. Why was it preferred to renunciation? I often asked myself the question, for this title long discouraged me from reading further. The answer is interesting. It came to the pen of the writer before the word renunciation and not afterward ; and it came before because a long residence in France had made the French form of a word more habitual than the English, which flowered upon her page in a landscape of French memories. A similar explanation should be remembered in regard to the essays, but I doubt how far it would affect most of the instances on which a critic would fasten. The Lover urges the Better Thrift is a good instance, because either the reader feels a certain euphuistic quality in these words, or he does not. Those who feel it can say only that it is not a title which Shakespeare would have chosen, or Wordsworth, the great master of idiom, or even Browning, who was ever ready to make the language dance to any, except an euphuistic, tune. Meredith might have used it ; but with him we desert our English idiom to indulge in a scholar's escapade. Like Carlyle, he improvised upon the language ; he never let it play its native tune. The result was a series of effects ; but these were dearly purchased by the cor- 


\section{The Collected Poems of Alice Meyned}

ruption of the language, which encouraged its further corruption in others. Preciousness, taken seriously, has been defined to be the learned corruption of language, which it teases into odd shapes and treats to affectations. Let the reader ask himself whether The Lover urges the Better Thrift is not a departure from the ease of English idiom.

It is just that Renouncement has become Mrs. Meynell's famous poem : the one poem which will always be quoted from her. No one will ever ask what she wrote. She is the author of Renouncement. To be identified with one work, in this sense, is to have attained the certainty of reputation. It is the most simple test, and the best. To revive the freshness of this familar piece, let us note first that it is a sonnet, and secondly how it has grown under her hand. The sonnet is the favourite, and properly the favourite, form of the smaller poets. It is the favourite form because it is the shortest metrical scheme yet acclimatized to English prosody. While the greatest poets, like Wordsworth, have been the greatest masters of the sonnet, the poets of the second rank, like Rossetti, have done well, even excellently, in this form. Its narrowness is a quality, not a defect, and like a Scotch burn, it is properly the haunt of the grayling and the minnows. Blanco White lives as the author of one sonnet. Mrs. Meynell will live chiefly as the author of another, around which her other poems will cluster like facets round the table of a gem. Her quality is a perfection of integrity which needs a small compass to display itself. Thus Renouncement suggests her range and in an inatince of its quality. To observe this, note, socoadly, the improvements made in the final version. "Love" has been changed to "thought" in the second and third lines, an obvious gain in directness. and perspicuity ; and "dearest" has become " sweetest" in the fourth line. This last change has involved 


\section{Blackfriars}

another : the substitution of "fairest" for " sweetest" in line five. These variorum readings may be excused because they give a new interest, as the changes have given a richer content, to a poem by now in danger of being too familiar to the reader. Let me note one other change which is also an improvement. The Lady of the Lambs has become The Shepherdess. Wordsworth would have liked the later title better.

Having inferred the compass of Mrs. Meynell's work from the fact that her famous piece is a sonnet, we shall know for what to hope, and for what not to look, in her work generally. A small compass implies intensity, and intensity, together with a small compass, implies an absence of vitality in the larger sense. If we turn to the drawing by Sargent which adorns the volume of Collected Poems, what do we see ? We see a tall, slender figure, the stem, as it were, of a delicate, refined face, a face a little weary, as if it were masked with the ashes of a fire which had wasted the spirit within. The distinction, the beauty is apparent, but there is the sense, often to be observed in an aristocratic face, of the end, of the weariness of a long road, most of which lies behind the traveller. The thread which binds the sheaf of Mrs. Meynell's verses is a thread of sadness. Renunciation, we perceive, is the characteristic subject, for her mind is preoccupied with tragic moments, moments bravely borne no doubt, but requiring bravery to bear them. Life is a burden to this poetess, not a joy. It imposes too great a strain upon her nerves. She has to brace herself to live, and is less conscious of life than of the daily price to be paid for living. In a poem entitled The Modern Mother, the mother hopes not for the love of her son but for his "forgiveness." Had she not bestowed upon him the tragic present of life? Again, in Parentage, a poem written before the War, we are told that women who bear children are the real slayers, because war and 


\section{The Collected Poems of Alice Meynell}

disease prey upon living things and everything which is born is led to the slaughter. The experiences which move her most, and the poignancy of which she uses all the resources of her art to prevent us from losing, are tragic, cruel moments ; and these she contemplates with the fascination of a magnet to its pole. An exquisite example of her talent in this kind is Maternity:

One wept whose only child was dead,

New-born, ten years ago.

"Weep not; he is in bliss," they said.

She answered, "even so.

Ten years ago was born in pain

A child, not now forlorn.

But oh, ten years ago, in vain,

A mother, a mother was born."

An acid touches every poem as with a cautery. Let us note a few touches which are the more revealing because they are touches only, shadows which steal upon her work like the twilight, little clouds which come between her spirit and the sun. In Veni Creator she asks, not if there is one Joy unknown to God, but if there is one " lowliness " unknown to Him, and cries :

Look at the mournful world Thou hast decreed,

and at the " hapless" men who know their " haplessness" within it. These adjectives coming spontaneously to her pen haunt her poems from the beginning. In Why wilt Thou Chide? the attainment is "to be denied" some one; and the rejected lover is told that no one can dare to "hope" for a part in his "despait." . In San Lorenzo's. Mother, a poem deservedly admired, the last verse runs as follows :

There is One alone who cannot change ;

Dreams are we, shadows, visions strange ; And all I give is given to One.

I might mistake my dearest son, But never the Son who cannot change. 


\section{Blackfriars}

The conviction which burns at the heart of this faith must not blind our eyes : the emphasis of the last two lines is distributed equally between them. If the emphasis was not so strong upon line four, the fifth line would be much weakened. Therefore we are conscious not only of the faith but of the tragic admission which has made this faith unfaltering. Again, in the charming poem, An Unmarked Festival, which celebrates the first chance meeting of two lovers, Mrs. Meynell is interested not only in the great event which came suddenly upon them, but that it went as it came for long unmarked. In The Unexpected Peril she is more explicit. Her youth, she says, was never "abounding " nor

In love with the sufficient day.

Her "first slumber nightly rehearsed" her "last." She goes still further :

\section{My shroud was in the flocks; the hill Within its quarry locked my stone ; \\ My bier grew in the woods ; and still Life spurred me where I paused alone.}

When the siege of her spirit was raised a little later, her new house-mate, "ease," filled her with hardly less misgiving, and in the end she implores the Angels of Labour and Pain, for it is "fear" which can best teach her.

The latest volume, $A$ Father of Women, abounds in similiar touches. In a poem upon the Lord's Prayer heaven is " unconceivable." The Thy Will is "inexorable yet implored"; the divine words are charged with an " unknown purpose." With a sense almost perverse she declares in The Two Questions that her mind is appalled not by the sufferings of the innocent heart, but by the punishment of the wicked : a 


\section{The Collected Poems of Alice Meynell}

point of view which (unless I misinterpret) is seeking for some subtlety of suffering where a healthy vitality would find joy. The most joyful of English poets, Thomas Traherne, the exquisite Anglican mystic, whose subject was always felicity, and Coventry Patmore, the most masculine of poets, are alike at least in this that both of them number among the pleasures of heaven the spectacle of thoroughly bad people receiving their deserts. But Mrs. Meynell would exchange that pleasure for some ache of pity or desire : without an edge she would hardly recognize her felicity. The Divine Privilege is " to be alone the sacrificed." In The Treasure life is

How weak,

How sad, how brief! O how divine, divine!

Indeed it is hardly too much to say that her imagination is only awakened fully by the spectacle of suffering, and when she sings it is in elegy. The Letter of a Girl to her own Old Age, with its long line of lamentation and the skilful droop of the feminine ending, is characteristic; and yet, if the spectacle of suffering were offered to her in its nakedness, as Mestrovic offered it to us all in his "Crucifixion," I fancy that she would turn away her eyes and declare that it was not bearable. Such a turning away I should regard as evidence of the truth of this criticism. We do turn away when we see ourselves face to face. Consequently Mrs. Meynell must place herself slightly at an oblique angle, and view the moments which possess her mind a little from one side. She shoots beside the mark rather than at it; and her arrows, like the bright glances of the robin, fly the straighter because they seem to spy their object from one side. This gives a bird-like quality to her writing, which is at once intense but detached.

We gain from her work, then, this : not, at first, an 


\section{Blackfriars}

extension of our humanity but an added sharpness to our consciousness. But in so far as this consciousness is concerned with experiences not peculiar in themselves, but common to all men, it is enriching. The experience of Strephon in St. Catharine of Siena is an experience of mankind; Catharine herself is feminine humanity. Hackneyed or official themes are transformed by this insight. Shakespeare's Tercentenaries become two dates in Mrs. Meynell's own life, and the death of Edith Cavell is seen as perhaps Edith herself saw it : a nurse who watched at her own death-bed, a woman who quietly waited for the dawn. We penetrate beyond the heroine of the copy-book to the natural woman, and go with her to meet her fate. This is the quality which raises Mrs. Meynell's verse to the highest point possible to its own order. Each poem, too, is carefully reasoned, and the reader who does not follow the argument will miss the whole; for intellectually no less than emotionally the verse has point. This intellectual concentration is a dangerous quality. Via et Veritas et Vita is an epigram, but a good one. Veni Creator and Why wilt Thou Chide? are, or are near to, intellectual conceits. The latter poem seems to offer an impossibly subtle consolation. Renunciation, consolation, how the theme recurs!

The limits of this poetry are sharply defined, and the substance is the clearer for them. That substance is true and genuine, but it is not gay or great. Joy is a quality of strength, and only in the greatest poets is intensity wholly free from tensity. The edge of a refined intelligence which we carry away from our reading has been gained by a tension of the nerves, which are robbed of some of their tone by the strain imposed upon them. We cannot repose upon this poetry. It is a tonic rather than a wine. It is life at its most intense, rather than at its highest, which we find here. For life at its highest is pure joy; at the 


\section{The Collected Poems of Alice Meynell}

centre of joy there is peace; and genius is too simple to be sad.

But that I may not seem to have bent the quotations to my argument or to have cast a preconceived shadow upon them, let me conclude with one quotation which shows her imagination at large and free. It comes from Christ in the Universe; and the subject of the poem is His dealing with other worlds than the earth :

Nor, in our little day,

May His devices with the heavens be guessed,

His pilgrimage to thread the Milky Way

Or His bestowals there be manifest.

But in the eternities,

Doubtless we shall compare together, hear

A million alien Gospels, in what guise

He trod the Pleiades, the Lyre, the Bear.

$\mathrm{O}$, be prepared, my soul !

To read the inconceivable, to scan

The million forms of God those stars unroll

When, in our turn, we show to them a Man.

That has a vitality, a splendour comparable to some of Francis Thompson's imagery : the lattice-window has been opened; we feel the breath of the sky. The air comes finely in on the thought here expressed. But we may not remain long at the open window, and are led by Mrs. Meynell to explore the interior of Humanity's familiar house.

OSBERT BURDETT.

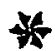

